\title{
Evaluation of Methods for Identifying Spawning Sites and Habitat Selection for Alosines
}

\author{
JULIANNE E. HARRIS* \\ North Carolina Cooperative Fisheries and Wildlife Research Unit, \\ Department of Biology, North Carolina State University, Raleigh, North Carolina 27695-7617, USA \\ Joseph E. Hightower \\ U.S. Geological Survey, North Carolina Cooperative Fish and Wildlife Research Unit, \\ Department of Biology, North Carolina State University, Raleigh, North Carolina 27695-7617, USA
}

\begin{abstract}
Characterization of riverine spawning habitat is important for the management and restoration of anadromous alosines. We examined the relative effectiveness of oblique plankton tows and spawning pads for collecting the eggs of American shad Alosa sapidissima, hickory shad A. mediocris, and "river herring" (a collective term for alewife A. pseudoharengus and blueback herring A. aestivalis) in the Roanoke River, North Carolina. Relatively nonadhesive American shad eggs were only collected by plankton tows, whereas semiadhesive hickory shad and river herring eggs were collected by both methods. Compared with spawning pads, oblique plankton tows had higher probabilities of collecting eggs and led to the identification of longer spawning periods. In assumed spawning areas, twice-weekly plankton sampling for 15 min throughout the spawning season had a $95 \%$ or greater probability of collecting at least one egg for all alosines; however, the probabilities were lower in areas with more limited spawning. Comparisons of plankton tows, spawning pads, and two other methods of identifying spawning habitat (direct observation of spawning and examination of female histology) suggested differences in effectiveness and efficiency. Riverwide information on spawning sites and timing for all alosines is most efficiently obtained by plankton sampling. Spawning pads and direct observations of spawning are the best ways to determine microhabitat selectivity for appropriate species, especially when spawning sites have previously been identified. Histological examination can help determine primary spawning sites but is most useful when information on reproductive biology and spawning periodicity is also desired. The target species, riverine habitat conditions, and research goals should be considered when selecting methods with which to evaluate alosine spawning habitat.
\end{abstract}

Anadromous alosines grow in productive marine waters and ascend coastal rivers when the temperature is appropriate for spawning (Mansueti 1962; Leggett and Whitney 1972; Loesch 1987; Limburg et al. 2003). These species support valuable recreational and commercial fisheries throughout their native ranges and are ecologically important because they import marine-derived nutrients into freshwater systems (Smith 1894; Garman 1992; Garman and Macko 1998; Limburg et al. 2003). As a result of overfishing and anthropogenic changes to spawning habitat in rivers, many populations are at historically low levels, and some are in critical need of conservation (Rulifson 1994; Hightower et al. 1996; Cooke and Leach 2003; Schmidt et al. 2003). Identifying and characterizing riverine spawning habitat may be critical to restore depleted alosine stocks.

A variety of methods are used to identify and characterize alosine spawning in rivers. Alosines are

\footnotetext{
* Corresponding author: jeharris@ncsu.edu
}

Received July 7, 2009; accepted November 27, 2009 Published online February 22, 2010 broadcast spawners, and most information on their spawning has been obtained by collecting eggs and larvae via various types of plankton nets (Massman 1952; Marcy 1972; Bilkovic et al. 2002; Overton and Rulifson 2007). Spawning habitat selection and timing can also be determined by direct observation of spawning behaviors (Leim 1924; Layzer 1974; Ross et al. 1993; Beasley and Hightower 2000), provided spawning events are identifiable and differentiable to species and observations can be made when spawning occurs. Examination of gonads by histology can be used to identify spawning locations and timing because gravid and recently spawned fish are often still on spawning grounds (Brewer et al. 2006). Histological examination of gonads has been used to differentiate female American shad Alosa sapidissima and hickory shad A. mediocris into maturity-classes (Olney et al. 2001; Olney and McBride 2003; Hyle 2004; Harris et al. 2007) and to describe spawning periodicity (Hyle 2004).

Four alosines are native to rivers on the Atlantic coast of North America: American shad, hickory shad, blueback herring A. aestivalis, and alewife A. psuedo- 
harengus. American shad spawn large (diameter, 2.5-4 $\mathrm{mm}$ ), relatively nonadhesive eggs in main-stem areas primarily between dusk and midnight (Leim 1924; Layzer 1974; Jones et al. 1978; Sparks 1998). Hickory shad eggs are smaller (0.98-1.65 mm), somewhat adhesive, and semidemersal but can be buoyant in flowing water (Mansueti 1962). Little is known about spawning habitat of hickory shad, but they appear to use both tributaries and main-stem areas (Sparks 1998; Burdick and Hightower 2006). Blueback herring and alewife eggs are difficult to distinguish and are often grouped as "river herring" eggs (Sparks 1998; Walsh et al. 2005), which are 0.80-1.11 mm, initially somewhat adhesive, and have been described as demersal, semidemersal, or pelagic (Jones et al. 1978). In river systems, alewives may prefer to spawn in lentic habitats, whereas blueback herring spawn in both lentic and lotic environments (Loesch and Lund 1977; Loesch 1987; Walsh et al. 2005).

The main purpose of our study was to compare the effectiveness of oblique plankton tows and spawning pads for characterizing alosine spawning habitat and timing. Plankton tows are commonly used to study spawning by alosines. In contrast, spawning pads have previously been used in rivers to collect eggs of Gulf sturgeon Acipenser oxyrinchus desotoi (Marchant and Shutters 1996; Sulak and Clugston 1998; Fox et al. 2000), white sturgeon A. transmontanus (Paragamian et al. 2001; Perrin et al. 2003), shortnose sturgeon $A$. brevirostrum (Duncan et al. 2004), paddlefish Polyodon spathula (Firehammer et al. 2006) and walleye Sander vitreus (Manny et al. 2007), but not alosines. Using information from our field study and published literature, we compared the effectiveness of plankton tows, spawning pads, direct observations of spawning, and examination of female histology for identifying spawning habitat and timing for North Carolina alosines. Comparisons were made in terms of cost, flexibility of use in different habitat types, time commitment in the field, and specific information obtained.

\section{Methods}

Plankton tow and spawning pad sampling was conducted at three locations on the Roanoke River in North Carolina: bypass, Roanoke Rapids, and Weldon; (Figure 1). All sites were below the most downstream dam (Roanoke Rapids Dam) located at river kilometer (rkm) 221. The bypass is the original river channel located adjacent to the tailrace of the Roanoke Rapids Dam; it was sampled as part of a study examining use of this rewatered habitat for spawning by anadromous fishes. The bypass is braided, shallow and characterized mainly by the presence of riffle and pool habitats.

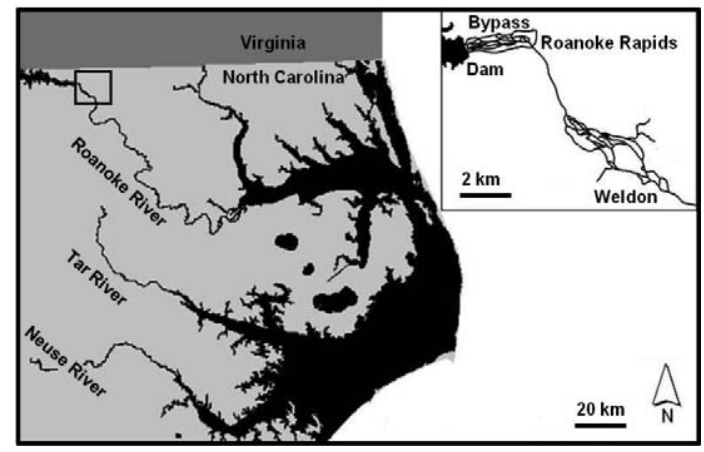

FIGURE 1.-Map of the Roanoke, Tar, and Neuse rivers; the inset shows the locations of the alosine egg sampling sites on the Roanoke River.

Sampling also occurred in the main channel just below the dam's tailrace at Roanoke Rapids (rkm 218) and slightly farther downstream at Weldon (rkm 209; Figure 1). In the Roanoke River, Roanoke Rapids is the predominant spawning area for American shad (Hightower and Sparks 2003), and Weldon is considered the main spawning area for hickory shad (Marshall 1977; Sparks 1998). River herring eggs have been collected at Roanoke Rapids, Weldon, and farther downstream (Sparks 1998; Walsh et al. 2005). In 2005, plankton tows and spawning pads were sampled in the bypass every $3 \mathrm{~d}$ from early March to late May. In 2006, sampling was completed once per week from early March to late May in the bypass and at Weldon and from early March to late July at Roanoke Rapids. In 2007, sampling was completed at Roanoke Rapids and Weldon approximately once per week from March to early July.

On each date, one 15-min oblique plankton tow was completed from a stationary position via a bongo frame with two $0.3-\mathrm{m}$ diameter plankton nets with $6: 1$ tail : mouth ratios and 500- $\mu \mathrm{m}$ mesh. A standard General Oceanics Environmental flowmeter was deployed next to the net to estimate the volume of water filtered. At Roanoke Rapids, tows were completed just after dark because American shad spawn there between dusk and midnight (Sparks 1998), and the site is just below the Roanoke Rapids Dam, so eggs cannot come from far upstream. Tows at Weldon and in the bypass were completed during the day because hickory shad and river herring eggs were successfully collected during the day in the bypass during 2005.

Polyester floor buffing pads, similar to those first used by Marchant and Shutters (1996) to collect Gulf sturgeon eggs, were used as spawning pads. Spawning pads were red, $0.5 \mathrm{~m}$ in diameter, and weighted to lie flat on the river bottom. The area sampled by an 
individual spawning pad was $0.196 \mathrm{~m}^{2}$. Spawning pads were specifically placed to sample the variety of depths, velocities, and sediment types present in the general location. The number of spawning pads examined could not be held constant over a season because some were destroyed, removed from the water, or washed away by high flows. Only sampling events in which five or more spawning pads were retrieved from a given site and examined for eggs were included in the analysis.

All eggs collected were immediately fixed in $5-10 \%$ buffered formalin in the field and later counted, identified, and staged for approximate age (using guides of Mansueti 1962; Jones et al. 1978; Burdick 2005). Eggs dead before fixation cannot be staged and in many cases cannot be confidently identified to species, so they are often removed from samples. For this study, the number of dead eggs found in a sample with American shad, hickory shad, or river herring eggs alive at the time of fixation (termed "live eggs") was tabulated if the dead eggs had the appropriate characteristics. However, the number of dead eggs was recorded only to evaluate the percentage of unusable eggs collected by a particular method (i.e., the percentage of dead versus live eggs); otherwise, all dead eggs were excluded from the analyses.

While completing plankton tows and examining spawning pads, we scanned the sampling location for visual evidence of spawning. Spawning behavior has been described for American shad and blueback herring (Walburg and Nichols 1967; Layzer 1974; Loesch and Lund 1977). American shad spawning behavior is described as multiple fish at the water's surface quivering and producing visible splashes (Walburg and Nichols 1967; Layzer 1974). Similarly, blueback herring spawning has been described as multiple fish swimming in a circular pattern near the surface before diving down to spawn (Loesch and Lund 1977). Sometimes in shallow water blueback herring can be observed darting back and forth while spawning (Loesch and Lund 1977). Spawning behaviors of hickory shad and alewives have not been described. The collection of young eggs $(\leq 1 \mathrm{~h}$ in age) might suggest that spawning occurred during the sampling period and could have been observed.

To determine the effectiveness of each gear, we examined its ability to identify spawning sites and spawning periods and to collect eggs that could be properly identified and staged. To evaluate the differences in the apparent length of the spawning season for each species, as estimated by plankton tows and spawning pads, we calculated the spawning period as the number of days from collection of the first egg to collection of the last egg for each year. The spawning period calculated by method (plankton tow or spawning pad) was compared using a paired $t$-test with years treated as replicates $(N=3$ years). In addition, we estimated probabilities of collecting at least one egg during a season for plankton tows and spawning pads, given different amounts of sampling effort. Probabilities were based on a binomial model (Ott and Longnecker 2001) and sampling from 1 to 10 times weekly within the average estimated spawning period for each alosine. If data from plankton tows and spawning pads produced different estimates of the spawning period, the longest average estimate was used. The probability of collecting at least one egg with either method was examined by sampling location and was set equal to the percentage of positive samples from that location during the estimated spawning periods.

The probability of collecting at least one egg from a site depends not only on the efficiency of the gear and sampling effort, but also on the species' population size and spawning periodicity, proximity of the sampler to the spawning location, river current and morphology, and other physical and environmental factors. Our samples were from presumed spawning sites, but many studies focus on locating and characterizing spawning sites throughout a river (Marcy 1972; Bilkovic et al. 2002; Smith 2006). To address efficiency under those objectives, we used published data from studies on the Neuse (Burdick 2005) and Tar (Smith 2006) rivers (both in North Carolina; Figure 1) to calculate the probability of collecting American shad and hickory shad eggs from multiple sites over a large portion of a river. Both studies employed the same plankton sampler as we used and both sampled each of their sites at least once per week for two complete spawning seasons. As in this study, Burdick (2005) completed 15-min oblique tows, whereas Smith (2006) completed 6-min tows consisting of $2 \mathrm{~min}$ on the bottom, $2 \mathrm{~min}$ in the midwater column, and 2 min near the surface (if water levels were very low, then 4-min tows were completed). The methods we used to estimate spawning periods and the probabilities of collecting at least one egg in both of these studies were the same as those we used for our field data.

Spawning pads are suggested for examining spawning microhabitat selection because adhesive eggs of some species have presumably been collected in close proximity to the location where spawning occurred (Marchant and Shutters 1996; Sulak and Clugston 1998; Firehammer et al. 2006). To evaluate whether eggs were collected nonrandomly with respect to spawning pads, catch per spawning pad during the spawning period at sites where eggs were collected was compared with a Poisson distribution using Pearson's 
TABLE 1.-Proportions of samples with eggs of American shad, hickory shad, and river herring and estimated egg densities, by sampling site (see Figure 1) and gear type. Density estimates were calculated as eggs $/ \mathrm{m}^{3}$ for plankton tows and eggs $/ \mathrm{m}^{2}$ for spawning pads. Also included is the proportion of live, identifiable eggs collected by each method.

\begin{tabular}{|c|c|c|c|c|c|c|}
\hline \multirow[b]{2}{*}{ Factor } & \multicolumn{2}{|c|}{ American shad } & \multicolumn{2}{|c|}{ Hickory shad } & \multicolumn{2}{|c|}{ River herring } \\
\hline & $\begin{array}{c}\text { Plankton } \\
\text { tows }\end{array}$ & $\begin{array}{l}\text { Spawning } \\
\text { pads }\end{array}$ & $\begin{array}{c}\text { Plankton } \\
\text { tows }\end{array}$ & $\begin{array}{l}\text { Spawning } \\
\text { pads }\end{array}$ & $\begin{array}{c}\text { Plankton } \\
\text { tows }\end{array}$ & $\begin{array}{c}\text { Spawning } \\
\text { pads }\end{array}$ \\
\hline Proportion with live eggs & 0.86 & & 0.78 & 0.66 & 0.78 & 0.58 \\
\hline \multicolumn{7}{|c|}{ Bypass } \\
\hline Proportion & 0.00 & 0.00 & 0.45 & 0.08 & 0.83 & 0.09 \\
\hline Density & 0.00 & 0.00 & 7.49 & 62.91 & 3.12 & 9.13 \\
\hline \multicolumn{7}{|c|}{ Roanoke Rapids } \\
\hline Proportion & 0.94 & 0.00 & 0.13 & 0.00 & 0.33 & 0.00 \\
\hline Density & 0.47 & 0.00 & $<0.01$ & 0.00 & 0.01 & 0.00 \\
\hline \multicolumn{7}{|c|}{ Weldon } \\
\hline Proportion & 0.30 & 0.00 & 1.00 & 0.31 & 1.00 & 0.04 \\
\hline Density & $<0.01$ & 0.00 & 1.09 & 287.76 & 0.17 & 0.26 \\
\hline
\end{tabular}

chi-square goodness-of-fit test. Spawning pads at sites where no eggs were collected during the season or that were sampled outside the detected spawning period were omitted from these analyses. Fits with similar values for the variance and mean suggest a random distribution; significantly higher values for the variance suggest a clumped distribution, and significantly lower values suggest a uniform distribution (Zar 1999). All tests were considered significant at $\alpha=0.05$.

To compare plankton tows, spawning pads, direct observation of spawning, and examination of female histology, we used a ranking system similar to that used by Diana et al. (2006) to evaluate sampling methods for round goby Neogobius melanostomus. Diana et al. (2006) used qualitative ranks from 1 (best) to 3 to evaluate each gear in terms of its flexibility of use in different habitats, its cost, and the time required to sample. We analyzed the ability of each method to provide data on spawning location, timing, and microhabitat characteristics. The method with the lowest sum ("score") for all categories was considered the most efficient for sampling spawning habitat because it provided the most information relative to its cost.

\section{Results}

Plankton tows collected eggs of all alosines at their predominant spawning sites, whereas spawning pads only collected hickory shad and river herring eggs (Table 1; Figure 1). American shad eggs were collected by plankton tows mainly from Roanoke Rapids, to a lesser extent from Weldon, and not at all from the bypass; however, the diel period of collection may have factored into the lack of catch in the bypass. Hickory shad eggs were collected most frequently at Weldon by both plankton tows and spawning pads, but also in the bypass by both methods. Only one hickory shad egg was collected from Roanoke Rapids by plankton sampling. River herring eggs were mainly collected from the bypass and Weldon with both plankton tows and spawning pads; they were also collected in low densities at Roanoke Rapids by plankton tows (Table 1). Additionally, one river herring egg was collected at Roanoke Rapids on a spawning pad; however, this date was removed from analysis because of the small number of spawning pads examined $(N=3)$. Both plankton tows and spawning pads identified main spawning sites for hickory shad and river herring; however, plankton tows collected eggs from a greater proportion of samples and collected some eggs from sites where only a small amount of spawning presumably occurred.

Compared with spawning pads, plankton tows identified longer spawning periods in all years, suggesting that they better document complete spawning runs. Hickory shad eggs were collected from midMarch to mid-April, with an average spawning period of $27.7 \mathrm{~d}(\mathrm{SE}=4.3)$ using data from plankton tows and $18.0 \mathrm{~d}(\mathrm{SE}=7.8)$ using data from spawning pads. River herring spawned from mid-April to mid-May; their average spawning period was $26.0 \mathrm{~d}(\mathrm{SE}=8.4)$ using data from plankton tows and $12.7 \mathrm{~d}(\mathrm{SE}=8.6)$ using data from spawning pads. The spawning period for river herring was significantly longer for plankton tows than for spawning pads (paired $t=5.71, \mathrm{df}=2, P$ $=0.029$ ) but that for hickory shad was not (paired $t=$ 2.36 , $\mathrm{df}=2, P=0.142$ ). Annually, the range and peak egg collections were similarly characterized by both methods (Figure 2). We were not able to compare gears for identifying the American shad spawning period because no eggs were collected with spawning pads. American shad spawned from early May to late June or 

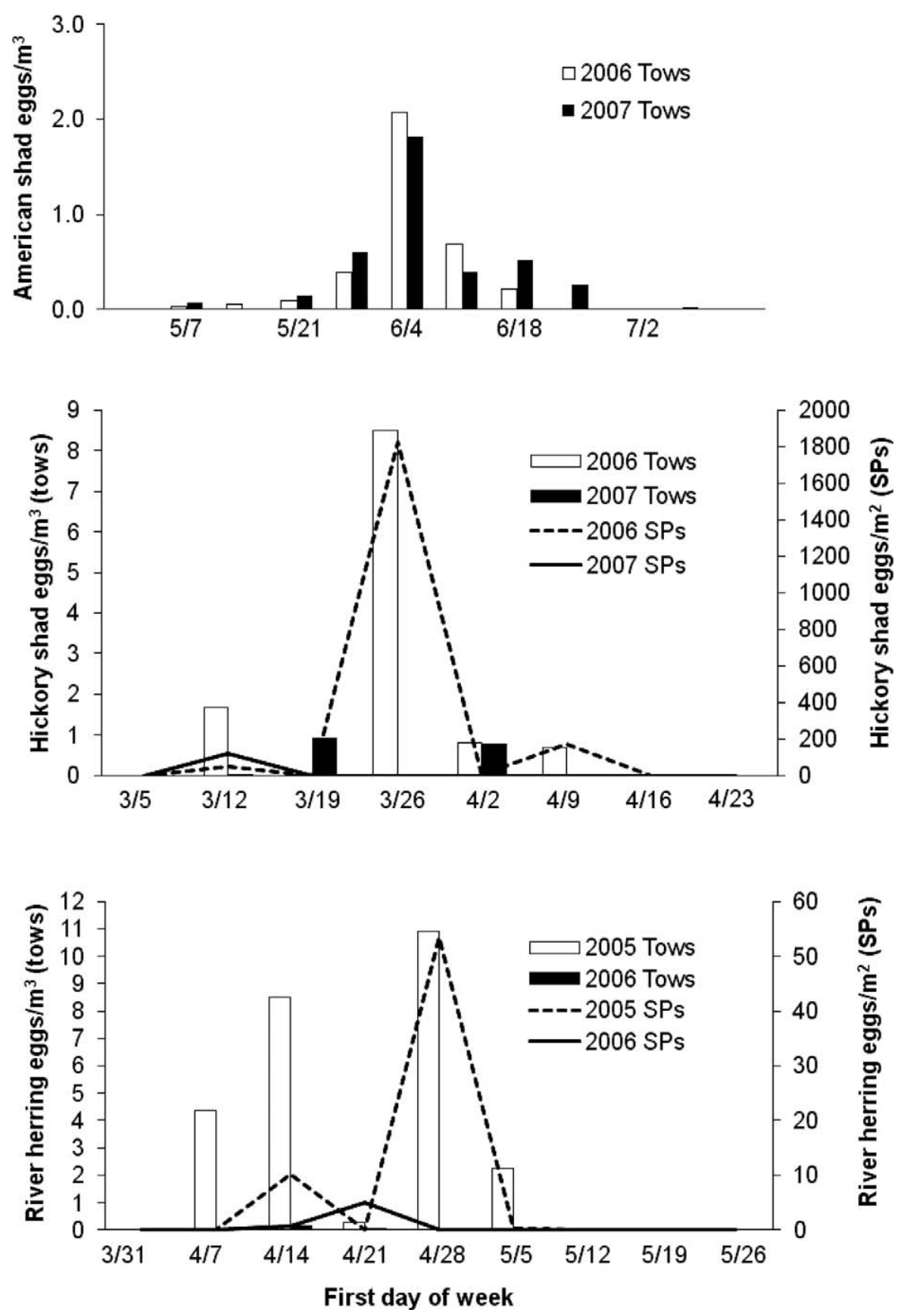

FIGURE 2.-Egg densities for American shad (Roanoke Rapids), hickory shad (Weldon), and river herring (the bypass), as determined from 15-min plankton tows and spawning pads (SPs), by weekly sampling period in 2005-2007.

early July; their average spawning period was $54.5 \mathrm{~d}$ $(\mathrm{SE}=6.5$; Figure 2).

The probability of collecting at least one egg from a site by weekly sampling was greater using plankton tows than spawning pads (Figure 3). With the exception of hickory shad at Roanoke Rapids, the probability of collecting at least one egg from every alosine species at any site was at least 0.95 for twiceweekly plankton tow sampling. Spawning pads did not collect eggs successfully when densities were low and 

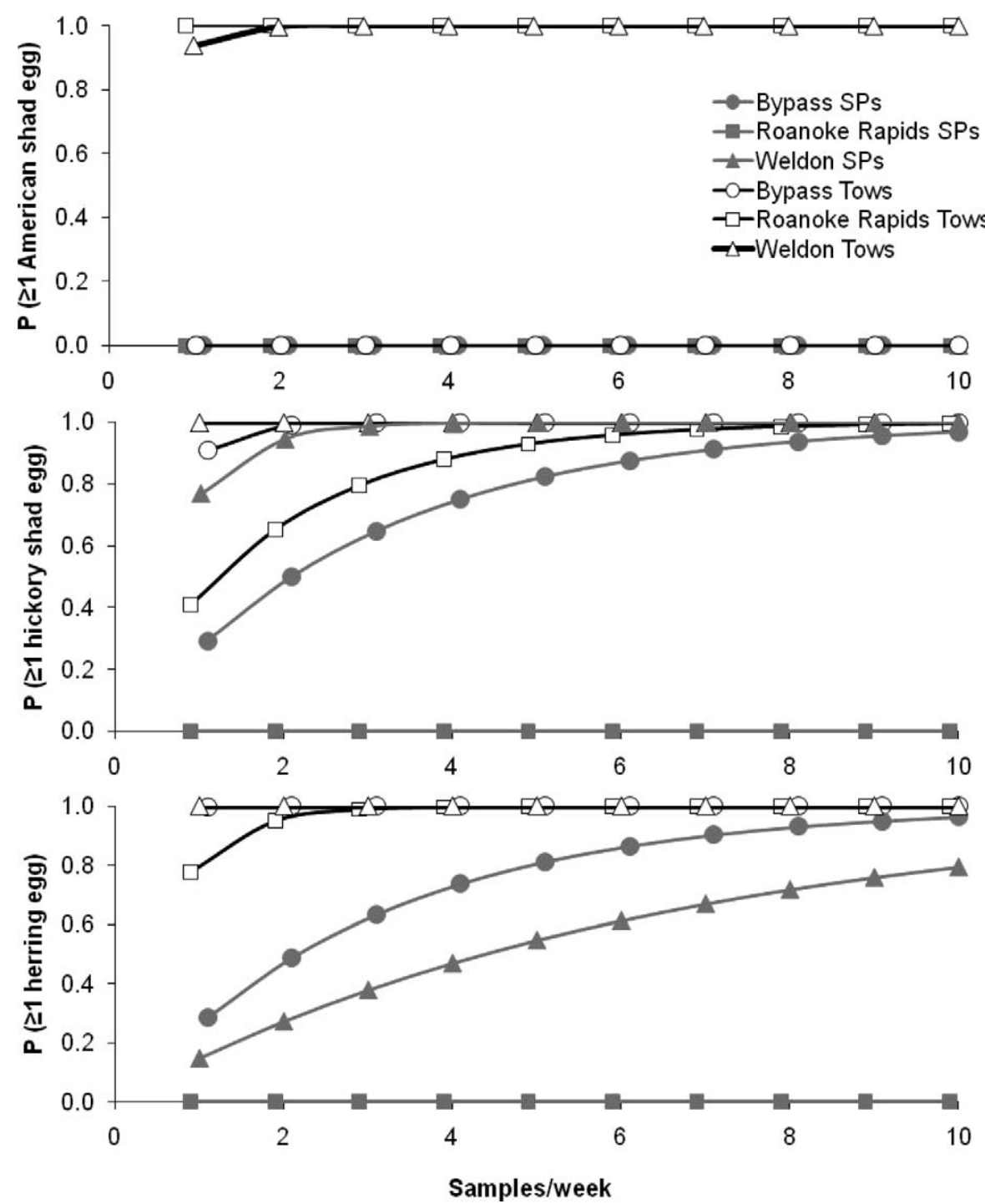

FIGURE 3.-Probability of collecting at least one American shad, hickory shad, or river herring egg during the spawning season in the Roanoke River with varying degrees of sampling effort per week. Samples were collected via either 15-min oblique plankton tows or spawning pads (SPs). The probabilities are based on a binomial model and represent the proportions of samples that contained at least one egg. Probabilities of zero indicate that no eggs were collected by that method in that sampling area.

generally required a greater number of samples to achieve a probability of collection above 0.95 (Figure 3). As an example, at Weldon 19 spawning pads would need to be sampled weekly to identify river herring spawning with a probability of 0.95 , compared with just one weekly plankton tow. Even for those alosines with eggs effectively collected by spawning pads, considerably more field effort would be required to achieve a similar probability of detecting spawning using spawning pads than using plankton tows.

The probability of collecting American shad and hickory shad eggs by plankton tows from randomly chosen sites in the Neuse and Tar river systems was river and site dependent (Figures 4, 5). In the Neuse River (data from Burdick 2005), the estimated spawning period averaged $83.5 \mathrm{~d}(\mathrm{SE}=12.5)$ for American shad and $61.5 \mathrm{~d}(\mathrm{SE}=10.5)$ for hickory shad. In the Tar River (data from Smith 2006), the average spawning period was estimated at $76 \mathrm{~d}(\mathrm{SE}=$ 12.0) for American shad and $64 \mathrm{~d}(\mathrm{SE}=4.0)$ for hickory shad. Plankton sampling had a higher probability of collecting at least one egg of either 

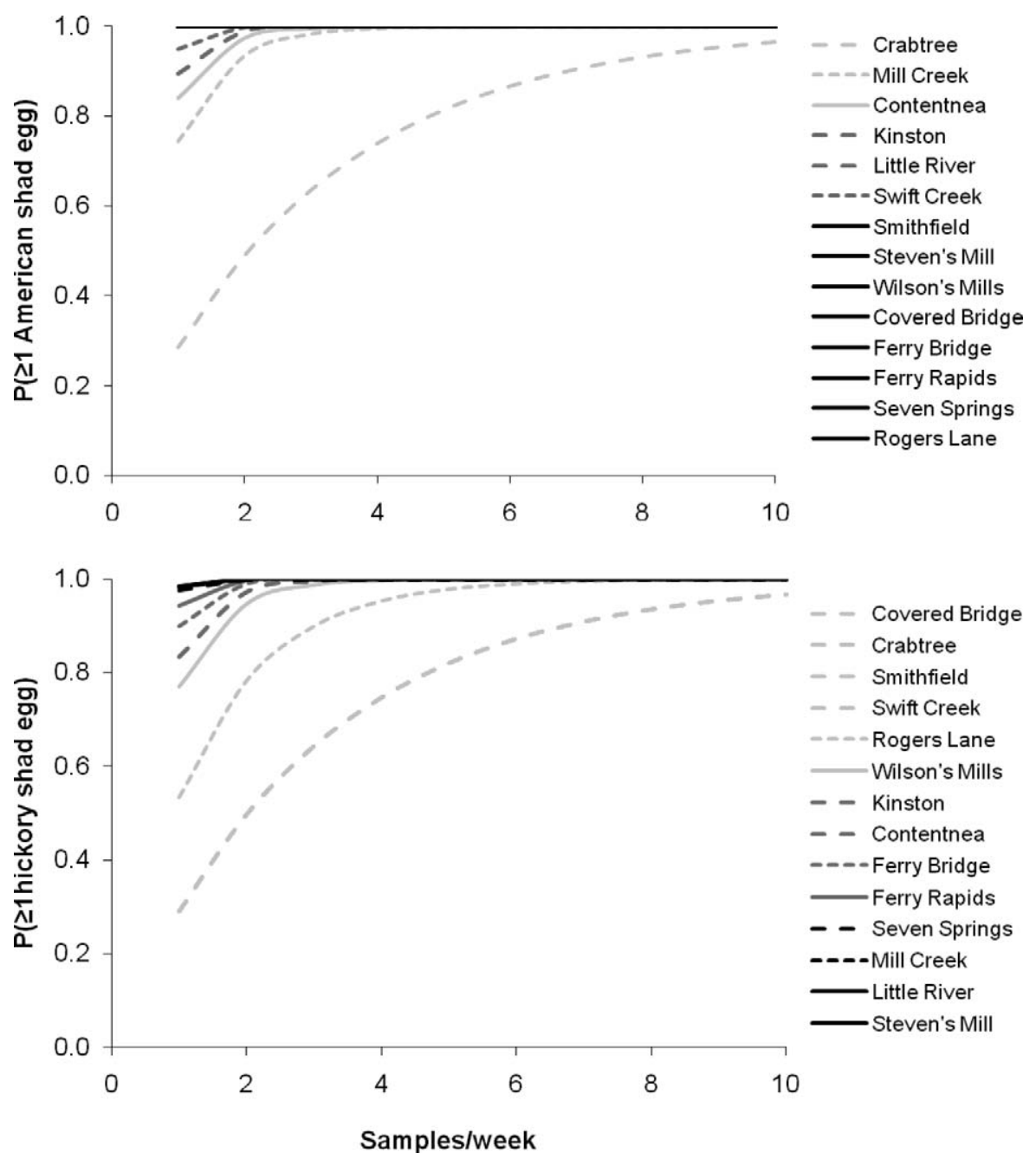

FIGURE 4.-Probability of collecting at least one American shad or hickory shad egg during the spawning season at different sites in the Neuse River with varying degrees of sampling effort per week (15-min oblique plankton tows; data from Burdick 2005). In the legends, the sites are ordered from the lowest to the highest probability of collecting at least one egg with a given amount of effort. See Figure 3 for additional details.

species for a given number of tows from more sites in the Neuse River than the Tar River (Figures 4, 5). This trend may be due to differences in the alosine population sizes, the distribution of spawning riverwide, or simply the length of the plankton tows: Burdick (2005) sampled for 15 min and Smith (2006) sampled for $6 \mathrm{~min}$. Similar to our field results in the Roanoke River, the probability of collecting eggs from areas of concentrated spawning was near or above 0.95 for twice-weekly sampling during the spawning period for both systems. Sites with low densities of eggs or those where eggs were collected only during 1 year had lower probabilities and would probably require more intensive sampling to guarantee collection of at least one egg. Sites where no eggs were collected in either year received a probability of zero under any level of sampling effort (Figure 5).

Most collected eggs were identifiable to stage and were young, indicating that sampling occurred within the temporal and spatial limits of spawning. Most eggs were less than $1 \mathrm{~h}$ in age, including all of the American shad eggs from Roanoke Rapids, $84 \%$ of the hickory shad eggs from Weldon and the bypass, and $78 \%$ of the river herring eggs from Weldon and the bypass. Similar age distributions were observed for hickory shad eggs collected by plankton tows and spawning pads, 

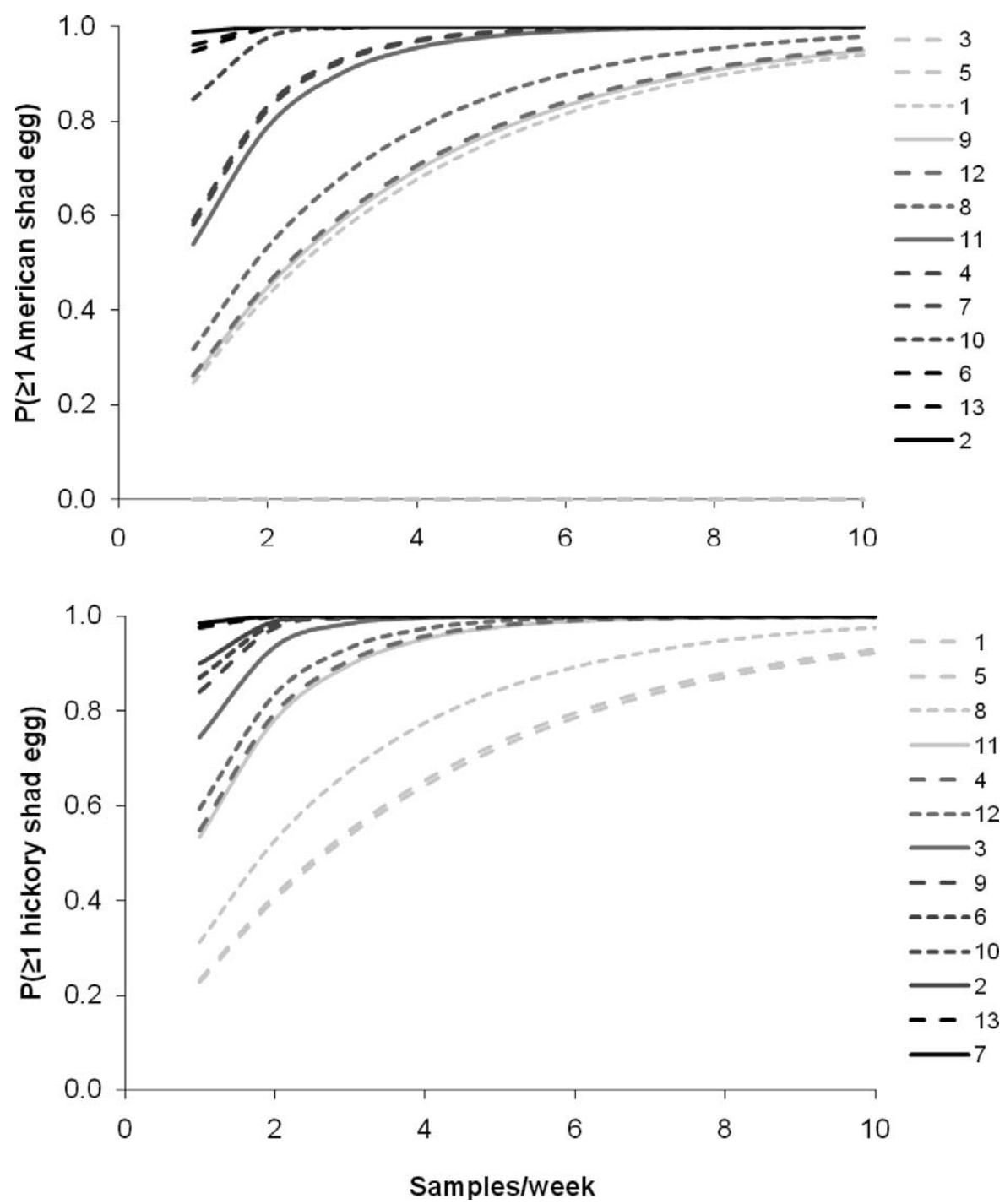

FIGURE 5.-Probability of collecting at least one American shad or hickory shad egg during the spawning season at different sites in the Tar River with varying degrees of sampling effort per week (6-min plankton tows; data from Smith 2006). In the legends, the sites are ordered from the lowest to the highest probability of collecting at least one egg with a given amount of effort. No American shad eggs were collected at sites 3 and 5; thus, the probability lines for those two sites coincide with the $x$ axis. See Figure 3 for additional details.

whereas a higher proportion of river herring eggs collected on spawning pads in the bypass were older than those collected by plankton tows in the same location (Figure 6). Hickory shad spawning was visually observed once in the bypass and once at Weldon, both instances during the afternoon in water less than $1 \mathrm{~m}$ deep. Spawning behavior was similar to that of American shad; fish moved rapidly and their fins could be seen near or above the water's surface. American shad spawning was observed on most evenings when their eggs were collected at Roanoke Rapids. River herring spawning was not observed on any occasion. The percentage of eggs that were dead and unidentifiable to stage appeared to vary by species and gear. A higher percentage of hickory shad and river herring eggs were dead compared with American shad eggs, and for both hickory shad and river herring, more dead eggs were collected by spawning pads than by plankton tows (Table 1).

Most spawning pads sampled during the spawning 

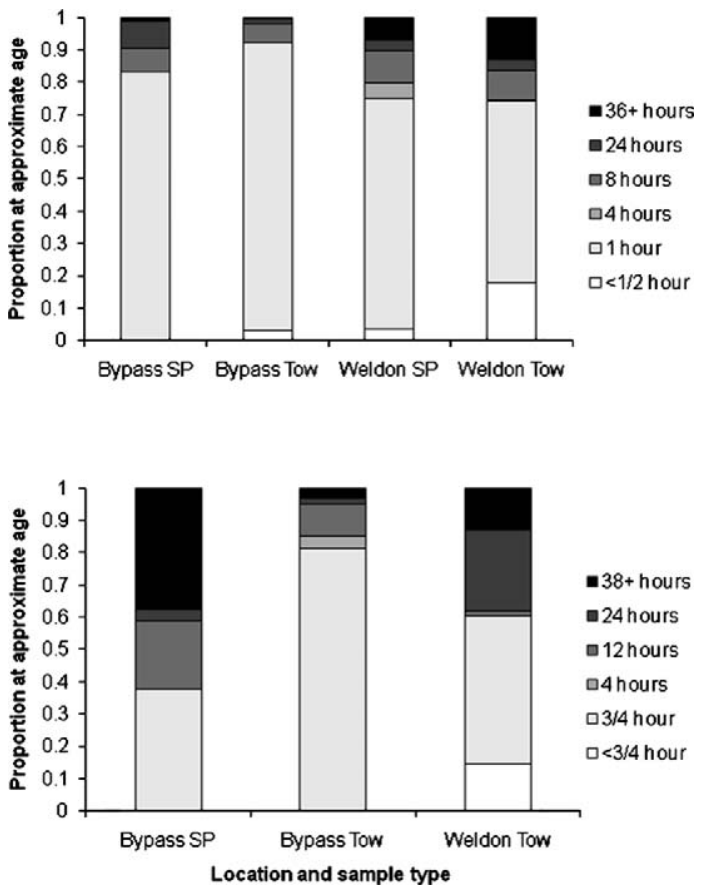

FiguRE 6.-Proportions of hickory shad (upper panel) and river herring (lower panel) eggs collected by spawning pads (SPs) and plankton tows from sampling sites in the Roanoke River, by egg age. Samples of less than 20 eggs are not included.

period contained no eggs (hickory shad $=81 \%$, river herring $=93 \%$ ). The number of eggs collected per spawning pad for hickory shad ranged from 0 to 2,458 and for river herring ranged from 0 to 150 . The distributions of both hickory shad and river herring eggs on the spawning pads were significantly different from the Poisson distribution and had much higher variances than means-hickory shad had a mean of 33 and a variance of 51,984 $(P<0.001)$ and river herring a mean of 2 and a variance of $144(P<0.001)$ suggesting clumped distributions.

The most efficient method for collecting information on spawning habitat and timing differed by species. The most effective and efficient method for American shad was direct observation of spawning (Table 2). Plankton tows received a lower ranking than direct observation of spawning because tows collect less information on diel timing and microhabitat selection for spawning, although they are less time-consuming and easier to complete in the field. Examination of female histology was generally less efficient and spawning pads were completely ineffective. For hickory shad, spawning was most efficiently characterized by spawning pads (Table 2). Plankton tows only received a slightly lower ranking because they collect less information on microhabitat selection, but they are quicker to complete and detect spawning earlier and later in the season. Direct observation of hickory shad spawning and examination of histology received the lowest rankings because spawning was not often observed and enough gravid females may be hard to collect. For river herring, plankton tows were the most efficient method for collecting spawning information, but histology of females and spawning pads were only slightly less efficient (Table 2). River herring eggs were not as effectively collected by spawning pads as were hickory shad eggs, but spawning pads were the only method to collect information on spawning microhabitat. Histology has a distinct advantage over the other methods for river herring because adult blueback herring and alewives can be differentiated to species. Spawning by river herring was not observed.

\section{Discussion}

Our results indicate that oblique plankton sampling is highly effective for collecting eggs of all alosines, whereas spawning pads appear only successful for adhesive eggs. Twice-weekly plankton sampling using oblique plankton tows had a high probability $(\geq 95 \%)$ of collecting eggs of all alosines at concentrated spawning sites and also often collected eggs in areas with only limited spawning. Spawning pads have a considerably lower probability of collecting eggs at a given level of effort than do plankton tows, and thus their use may result in the identification of fewer spawning sites riverwide and the estimation of shorter seasonal spawning periods. Spawning pads did identify main spawning sites for hickory shad and river herring and, similar to findings for Gulf and shortnose sturgeon eggs (Marchant and Shutters 1996; Duncan et al. 2004), collected eggs in clumped distributions. This supports pad use to evaluate microhabitat selection for alosines and other river-spawning fishes with adhesive eggs, especially those that spawn near the bottom or have negatively buoyant eggs.

Plankton sampling would be a preferred method for collecting information on spawning site selection and the seasonal spawning period, especially if little about a particular population is known or if information about multiple alosines is desired. Plankton sampling is logistically simple and generally requires relatively little time at each field site ( $<30 \mathrm{~min}$ for a $15 \mathrm{~min}$ tow), allowing a modest crew to collect information over a large portion of a river during a given season (Weisberg and Burton 1993; Bilkovic et al. 2002; Burdick and Hightower 2006; Smith 2006). Riverwide sampling helps locate areas of concentrated spawning in a system, especially when sites with high concen- 
TABLE 2.- Ratings of four methods of sampling spawning habitat for American shad (A), hickory shad (H), and river herring (R) based on eight factors, where $1=$ excellent, $2=$ fair, $3=$ poor and $\mathrm{NE}=$ did not appear to be effective for identifying spawning in a large river. Lower overall scores indicate greater effectiveness.

\begin{tabular}{|c|c|c|c|c|c|c|c|c|c|c|c|c|}
\hline \multirow[b]{2}{*}{ Factor } & \multicolumn{3}{|c|}{ Plankton tows } & \multicolumn{3}{|c|}{ Spawning pads } & \multicolumn{3}{|c|}{ Observation of spawning } & \multicolumn{3}{|c|}{ Female histology } \\
\hline & A & $\mathrm{H}$ & $\mathrm{R}$ & A & $\mathrm{H}$ & $\mathrm{R}$ & A & $\mathrm{H}$ & $\mathrm{R}$ & A & $\mathrm{H}$ & $\mathrm{R}$ \\
\hline Ease of use & 1 & 1 & 1 & $\mathrm{NE}$ & 1 & 1 & 2 & 2 & $\mathrm{NE}$ & 1 & 1 & 1 \\
\hline Equipment cost & 2 & 2 & 2 & NE & 2 & 2 & 1 & 1 & NE & 2 & 2 & 2 \\
\hline Field time commitment & 1 & 1 & 1 & $\mathrm{NE}$ & 2 & 2 & 2 & 3 & NE & 2 & 2 & 2 \\
\hline Usability in different habitats & 2 & 2 & 2 & $\mathrm{NE}$ & 1 & 1 & 2 & 2 & $\mathrm{NE}$ & 1 & 1 & 1 \\
\hline Spawning site selection & 1 & 1 & 1 & $\mathrm{NE}$ & 1 & 2 & 1 & 1 & $\mathrm{NE}$ & 1 & 1 & 1 \\
\hline Spawning microhabitat & 3 & 3 & 3 & $\mathrm{NE}$ & 1 & 2 & 1 & 1 & NE & 3 & 3 & 3 \\
\hline Seasonal timing of spawning & 1 & 1 & 1 & $\mathrm{NE}$ & 2 & 3 & 1 & 3 & $\mathrm{NE}$ & 2 & 3 & 2 \\
\hline Diel timing of spawning & 2 & 2 & 2 & $\mathrm{NE}$ & 2 & 2 & 1 & 3 & $\mathrm{NE}$ & 3 & 3 & 3 \\
\hline Method score (total) & 13 & 13 & 13 & $\mathrm{NE}$ & 12 & 15 & 11 & 16 & $\mathrm{NE}$ & 15 & 16 & 15 \\
\hline
\end{tabular}

trations of eggs can be identified. Plankton tows have been used not only to locate spawning sites but also to identify spawning in newly accessible areas previously blocked by a dam (Burdick and Hightower 2006) or areas of poor water quality (Weisburg and Burton 1993). Plankton nets collect eggs even when densities are low and, thus, might be the most effective method in systems with small or depressed populations. In such cases, increased sampling intensity may be required. Catch of American shad eggs can vary by diel period (Layzer 1974; Burdick 2005) and net location in the water column (Massman 1952); thus, these logistics should be considered before starting a project. Although often useful, some plankton nets and protocols may not be feasible in systems with high or changing water velocities or high concentrations of debris or algae because drag from water pressure and material could clog nets (Overton and Rulifson 2007) and reduce egg collection. Also, plankton tows collect eggs that may have floated down from an undetermined spawning site upstream (Marcy 1972; Layzer 1974). This disadvantage can be partially offset by staging eggs to estimate their approximate age, so that inferences can be made about the distance to upstream spawning locations (Burdick and Hightower 2006). However, eggs float for an indeterminate amount of time in the water column and developmental rates vary by individual and with temperature (Mansueti 1962; Jones et al. 1978), making age assignments only approximate and possibly leading to imprecise estimates of specific spawning sites, especially if few young eggs are collected. In our study, most eggs were young ( $\leq 1 \mathrm{~h}$ in age), suggesting that they were spawned nearby; however some eggs were older and suggest additional spawning upstream. Sites where only a few eggs were collected, such as Roanoke Rapids for hickory shad and Weldon for American shad, may represent areas that eggs have floated into, rather than selected spawning sites. In contrast, areas where large numbers of young eggs are collected probably represent main spawning sites. Plankton sampling is an excellent method to identify spawning areas and the annual spawning period, however, they often do not provide good information about spawning microhabitat.

In contrast, direct observations of spawning and collection of eggs by spawning pads are highly effective methods for studying microhabitats selected for spawning. Fine-scale information on spawning habitat requirements is important for, and often lacking from, flow modeling studies in regulated rivers (e.g., instream flow incremental method of Bovee 1982). Direct observations are optimal when spawning fish can be identified to species and when detectability is high and constant across time and habitat types because there is no uncertainty about when and where spawning occurred. Additionally, when spawning is visible, no added equipment or laboratory processing is required, leading to comparatively lower costs. Spawning splashes have been used in multiple studies to identify spawning microhabitat and the diel spawning period for American shad (Leim 1924; Layzer 1974; Ross et al. 1993; Beasley and Hightower 2000) since their spawning behavior appears both highly visible in a variety of habitats and generally correlated with the collection of young eggs (Layzer 1974; Ross et al. 1993). A critical question, however, is whether some spawning occurs below the surface that is undetected visually. Layzer (1974) reported the collection of eggs at one location where spawning splashes were not observed and suggested that spawning splashes may not be as evident at sites with deep water. Visual observations of spawning were rare for hickory shad and nonexistent for river herring at our main-stem sampling locations, suggesting that direct observation may not be a viable option for these species in large, turbid systems where spawning is likely to be missed. To identify the spawning behavior of chum salmon 
Oncorhynchus keta, Tiffan et al. (2005) used a combination of visual observation and footage from underwater cameras during the day (when spawning was visible) and dual-frequency identification sonar at night (when it was not). For systems with adequate water clarity, underwater cameras and snorkeling could be used to validate species identifications from visual observations. For deep or turbid waters the combination of traditional sampling gears and acoustic techniques could be effective for describing spawning behavior.

Spawning pads are an effective sampling gear for alosines with adhesive eggs. Sampling multiple spawning pads, as done in this study, would be needed to equal the effectiveness of one plankton tow sample, which would require a greater time commitment per site in the field. Examining and removing eggs from one spawning pad can take various amounts of time (depending on the number of eggs and the type and amount of sediment deposited on the pad), but it is often more than that required to complete a 15-min plankton tow in the field. Another disadvantage of spawning pads is that they must be left in the river, sometimes for multiple days, and thus can be disturbed by people, washed out by high flows, or covered by fine sediments. Firehammer et al. (2006) found spawning pads difficult to use for collecting paddlefish eggs in the Yellowstone River because the samplers were constantly being covered or buried by sediment. In response, they created spawning tubes, which were made with similar material but held the sampler in the water column, so it would not become covered by shifting sediments (Firehammer et al. 2006). The pads we used were never buried but were sometimes coated with sand, which may have reduced their ability to sample eggs. However, despite being sometimes mixed in with sand, hickory shad and river herring eggs were still sampled by spawning pads. It is possible that sedimentation resulted in the higher percentage of dead eggs from spawning pads than from plankton tows. Kock et al. (2006) found that when covered by silt, adhesive white sturgeon eggs had reduced survival and growth in the laboratory. Also, numerous spawning pads were lost downstream or were unable to be sampled during periods of high flows, thus reducing sample size. Spawning pads generally sampled young eggs, suggesting that they may most effectively collect eggs during the initial stages when eggs are most adhesive (Mansueti 1962; Jones et al. 1978). Thus, similar to plankton tows, if eggs are not spawned constantly during the day, the diel period when spawning pads are examined may affect the number of eggs collected. The best use of spawning pads and direct observation of spawning may be for fine-scale studies of spawning habitat use when general information on spawning sites and periods has been obtained for the system.

To evaluate spawning habitat selection, a sampling method must either be similarly effective under different conditions or an understanding of its effectiveness in different habitat types is required. It can be difficult to determine the effectiveness of a sampling method under different field conditions because differences in the intensity of use in habitats could be confounded with differences in gear effectiveness. Relative effectiveness can be determined through sideby-side sampling using multiple methods. For example, Duncan et al. (2004) attached plankton nets to spawning pads to collect shortnose sturgeon eggs, Layzer (1974) observed spawning splashes and set plankton nets to detect American shad spawning, and Aunins and Olney (2009) used both bongo and set plankton nets to collect American shad eggs. In general, oblique plankton tows work well in areas with adequate depth and directional flow, whereas push nets may be more useful in low-flow areas when eggs are buoyant. Bottom set nets could work well in shallow rocky areas or areas with low or tidally influenced flow, where eggs would be expected to settle out near the bottom (Williams et al. 1975; Hightower and Sparks 2003; Walsh et al. 2005; Burdick and Hightower 2006; Aunins and Olney 2009). Spawning splashes may be most visible in shallow areas with high water clarity (Layzer 1974), and spawning pads may be most effective in areas with low sediment deposition (Firehammer et al. 2006). Further research to quantify the effectiveness of sampling methods under different environmental conditions would be helpful for selecting a single sampling method or a combination of methods in future studies.

The method least affected by differences in habitat or environmental conditions may be the examination of female gonads by histology. Histology has been suggested to evaluate spawning sites and habitats for fishes in large river systems, where spawning cannot be observed visually (Brewer et al. 2006). Full characterization of maturity-classes by histology for North American alosines has only been completed for American shad (Olney et al. 2001). American shad are batch spawners (Olney et al. 2001; Olney and McBride 2003), and the proximity of a female to releasing a batch of eggs can be determined by examination of the gonads (Olney et al. 2001; Hyle 2004). Histology, which can be used to determine both spawning frequency and the diel timeframe when spawning occurs (Hyle 2004), offers the distinct advantage of using adult spawners that can easily be 
differentiated to species and collected by a combination of field methods (Olney and McBride 2003). Therefore, adult spawners can be collected from a variety of habitats while completing other forms of sampling during the spawning period. Additional information about the spawning cycle and fecundity can also be determined by examining gonads histologically (Olney et al. 2001; Hyle 2004). These studies have not been done for most alosines but would contribute greatly to the understanding of their biology. Histological preparation may be more costly than other methods and could require a large sample of adult spawners to precisely evaluate proximity of spawning sites and diel spawning periods. The sacrifice of numerous individuals could be problematic for depressed or listed populations or species, such as Alabama shad $A$. alabamae (Jelks et al. 2008). In general, examination of histology is not likely to be the most efficient method for collecting information about spawning site selection or timing, unless it otherwise fits into a sampling protocol and additional information on reproductive biology is desired.

Seasonal spawning periods for alosines on the Atlantic coast are thought to be dependent on river water temperature (Leggett and Whitney 1972; Loesch 1987; Harris et al. 2007). The spawning periods estimated for American shad and hickory shad from plankton tow data collected riverwide in the Neuse (Burdick 2005) and Tar (Smith 2006) rivers were longer than those estimated using our plankton tow data from specific spawning sites collected over a small range of the Roanoke River (rkm 209 to 221). Spawning may occur over a shorter period in the Roanoke River; however, Walsh et al. (2005) obtained much longer spawning periods than we did using age data from larval blueback herring and alewives collected in the river. This suggests that by sampling only a few specific spawning sites we obtained spawning periods shorter than the actual riverwide period. The longer spawning periods derived from riverwide studies suggest that spawning varies seasonally across sites within the river system, perhaps as a result of differences in water temperature and other environmental factors. A riverwide sampling design could not only help locate sites of concentrated spawning but also better identify the complete seasonal spawning periods.

Selection of an appropriate design for field studies depends not only on the research objectives and species of concern but also on the time commitment and expense. Although the methods we evaluated (plankton tows, spawning pads, direct observation of spawning, and examination of female histology) would be relatively inexpensive and require only a crew of two, they could be time-consuming and entail other costs that would vary with the particular research objective and study system. Each method may require the use of a boat to obtain samples, and all but direct observations of spawning would require a dissecting microscope and considerable time spent in the laboratory sorting and examining eggs and (or) preparing and reading histology slides. Regardless, differences in direct costs are unlikely to be prohibitive; thus, selection of a method should be guided more by the overall research objectives of the program, the availability of field and laboratory technicians, and the specific species and research questions to be addressed.

In summary, methods and sampling protocols selected to evaluate spawning timing and habitat selectivity depend on the species in question and the overall research objectives of the program and specific study. When little is known about the species' biology or a systemwide understanding of spawning is required, plankton tows would probably be a good first step. To obtain more specific information on microhabitat use and reproduction, alternative methods (e.g., spawning pads, direct observation of spawning, and examination of female histology) could be more appropriate. Identification of spawning sites and characterization of specific spawning habitat requirements for alosines is warranted to better manage populations and understand the effects of anthropogenic changes to river systems.

\section{Acknowledgments}

We greatly thank Nicole Antaya, Jessica Baumann, Jenny Bearden, Christin Brown, Patrick Cooney, Warren Mitchell, and Caroline Paulsen for assistance with field work and Jeff Buckel, Robert Graham, Pete Kornegay, Thomas Kwak, and Kenneth Pollock for help with study design, analysis, and review of this manuscript. This manuscript was also improved by comments from Nick Trippel. This work was funded by Dominion/North Carolina Power and the North Carolina Wildlife Resources Commission. The North Carolina Cooperative Fisheries and Wildlife Research Unit is jointly supported by North Carolina State University, North Carolina Wildlife Resources Commission, U.S. Geological Survey, and Wildlife Management Institute. Reference to any trade name does not suggest endorsement by the U.S. Government or the U.S. Geological Survey.

\section{References}

Aunins, A., and J. E. Olney. 2009. Migration and spawning of American shad in the James River, Virginia. Transactions of the American Fisheries Society 138:1392-1404.

Beasley, C. A., and J. E. Hightower. 2000. Effects of a low- 
head dam on the distribution and characteristics of spawning habitat used by striped bass and American shad. Transactions of the American Fisheries Society 129:1316-1330.

Bilkovic, D. M., J. E. Olney, and C. H. Hershner. 2002. Spawning of American shad (Alosa sapidissima) and striped bass (Morone saxatilis) in the Mattaponi and Pamunkey Rivers, Virginia. U.S. National Marine Fisheries Service Fishery Bulletin 100:632-640.

Bovee, K. 1982. A guide to stream habitat analysis using instream flow incremental methodology. U.S. Fish and Wildlife Service FWS/OBS-82/26. (Instream Flow Information Paper 12)

Brewer, S. K., D. M. Papoulias, and C. F. Rabeni. 2006. Spawning habitat associations and selection by fishes in a flow-regulated prairie river. Transactions of the American Fisheries Society 135:763-778.

Burdick, S. M. 2005. Distribution of spawning activity by migrating fishes in the Neuse River, North Carolina, after removal of a low-head dam. Master's thesis. North Carolina State University, Raleigh.

Burdick, S. M., and J. E. Hightower. 2006. Distribution of spawning activity by anadromous fishes in an Atlantic slope drainage after removal of a low-head dam. Transactions of the American Fisheries Society 135:1290-1300.

Cooke, D. W., and S. D. Leach. 2003. Beneficial effects of increased river flow and upstream fish passage on anadromous alosine stocks. Pages 331-338 in K. E. Limburg and J. R. Waldman, editors. Biodiversity, status, and conservation of the world's shads. American Fisheries Society, Symposium 35, Bethesda, Maryland.

Diana, C. M., J. L. Jonas, R. M. Claramunt, J. D. Fitzsimons, and J. E. Marsden. 2006. A comparison of methods for sampling round goby in rocky littoral areas. North American Journal of Fisheries Management 26:514-522.

Duncan, M. S., J. J. Isley, and D. W. Cooke. 2004. Evaluation of shortnose sturgeon spawning in the Pinopolis Dam tailrace, South Carolina. North American Journal of Fisheries Management 24:932-938.

Firehammer, J. A., D. L. Scarnecchia, and S. R. Fain. 2006. Modification of a passive gear to sample paddlefish eggs in sandbed spawning reaches of the lower Yellowstone River. North American Journal of Fisheries Management 26:63-72.

Fox, D. A., J. E. Hightower, and F. M. Parauka. 2000. Gulf sturgeon spawning migration and habitat in the Choctawhatchee River system, Alabama-Florida. Transactions of the American Fisheries Society 129:811-826.

Garman, G. C. 1992. Fate and potential significance of postspawning anadromous fish carcasses in an Atlantic coastal river. Transactions of the American Fisheries Society 121:390-394.

Garman, G. C., and S. A. Macko. 1998. Contribution of marine-derived organic matter to an Atlantic coast, freshwater, tidal stream by anadromous clupeid fishes. Journal of the North American Benthological Society 17:277-285.

Harris, J. E., R. S. McBride, and R. O. Williams. 2007. Life history of hickory shad in the St. Johns River, Florida. Transactions of the American Fisheries Society 136:1463-1471.
Hightower, J. E., and K. L. Sparks. 2003. Migration and spawning habitat of American shad in the Roanoke River, North Carolina. Pages 193-199 in K. E. Limburg and J. R. Waldman, editors. Biodiversity, status, and conservation of the world's shads. American Fisheries Society, Symposium 35, Bethesda, Maryland.

Hightower, J. E., A. M. Wicker, and K. M. Endres. 1996. Historical trends in abundance of American shad and river herring in Albemarle Sound, North Carolina. North American Journal of Fisheries Management 16:257-271.

Hyle, A. R. 2004. Reproductive biology of American shad, Alosa sapidissima, in the Mattaponi River. Master's thesis. College of William and Mary, Williamsburg, Virginia.

Jelks, H. L., S. J. Walsh, N. M. Burkhead, S. ContrerasBalderas, E. Diaz-Pardo, D. A. Hendrickson, J. Lyons, M. E. Mandrak, F. McCormick, J. S. Nelson, S. P. Platania, B. A. Porter, C. B. Renaud, J. J. Schmitter-Soto, E. B. Taylor, and M. L. Warren Jr. 2008. Conservation status of imperiled North American freshwater and diadromous fishes. Fisheries 33:372-407.

Jones, P. W., F. D. Martin, and J. D. Hardy Jr. 1978. Development of fishes of the Mid-Atlantic Bight, volume 1. Chesapeake Biological Laboratory, University of Maryland, Solomons.

Kock, T. J., J. L. Congleton, and P. J. Anders. 2006. Effects of sediment cover on survival and development of white sturgeon embryos. North American Journal of Fisheries Management 26:134-141.

Layzer, J. B. 1974. Spawning sites and behavior of American shad, Alosa sapidissima (Wilson), in the Connecticut River between Holyoke and Turners Falls, Massachusetts, 1972. Master's thesis. University of Massachusetts, Amherst.

Leggett, W. C., and R. R. Whitney. 1972. Water temperature and the migrations of American shad. U.S. National Marine Fisheries Service Fishery Bulletin 70:659-670.

Leim, A. H. 1924. The life history of shad, Alosa sapidissima (Wilson), with special reference to the factors limiting its abundance. Contributions to Canadian Biology and Fisheries 2:163-284.

Limburg, K. E., K. A. Hattala, and A. Kahnle. 2003. American shad in its native range. Pages 125-140 in K. E. Limburg and J. R. Waldman, editors. Biodiversity, status, and conservation of the world's shads. American Fisheries Society, Symposium 35, Bethesda, Maryland.

Loesch, J. G. 1987. Overview of life history aspects of anadromous alewife and blueback herring in freshwater habitat. Pages 89-103 in M. J. Dadswell, R. J. Klauda, C. M. Moffitt, and R. L. Saunders, editors. Common strategies of anadromous and catadromous fishes. American Fisheries Society, Symposium 1, Bethesda, Maryland.

Loesch, J. G., and W. A. Lund Jr. 1977. A contribution to the life history of blueback herring, Alosa aestivalis. Transactions of the American Fisheries Society 106:583-589.

Manny, B. A., G. W. Kennedy, J. D. Allen, and J. R. P. French III. 2007. First evidence of egg deposition by walleye (Sander vitreus) in the Detroit River. Journal of Great Lakes Research 33:512-516.

Mansueti, R. J. 1962. Eggs, larvae, and young of the hickory 
shad, Alosa mediocris, with comments on its ecology in the estuary. Chesapeake Science 3:173-205.

Marchant, S. R., and M. K. Shutters. 1996. Artificial substrates collect Gulf sturgeon eggs. North American Journal of Fisheries Management 16:445-447.

Marcy, B. C. Jr. 1972. Spawning of American shad, Alosa sapidissima, in the lower Connecticut River. Chesapeake Science 13:116-119.

Marshall, M. D. 1977. Status of hickory shad in North Carolina. Pages 33-45 in R. A. St. Pierre, editor. Proceedings of a workshop on American shad. U.S. Fish and Wildlife Service and U.S. National Marine Fisheries Service, Washington, D.C.

Massman, W. H. 1952. Characteristics of spawning areas of shad, Alosa sapidissima (Wilson), in some Virginia streams. Transactions of the American Fisheries Society 81:78-93.

Olney, J. E., S. C. Denny, and J. M. Hoenig. 2001. Criteria for determining maturity stage in female American shad, Alosa sapidissima, and a proposed reproductive cycle. Bulletin Français de la Peche et de la Pisciculture 362/ 363:881-901.

Olney, J. E., and R. S. McBride. 2003. Intraspecific variation in batch fecundity of American shad: revisiting the paradigm of reciprocal latitudinal trends in reproductive traits. Pages 185-192 in K. E. Limburg and J. R. Waldman, editors. Biodiversity, status, and conservation of the world's shads. American Fisheries Society, Symposium 35, Bethesda, Maryland.

Ott, R. L., and M. Longnecker. 2001. Statistical methods and data analysis, 5th edition. Duxbury Wadsworth Group Pacific Grove, California.

Overton, A. S., and R. A. Rulifson. 2007. Evaluation of plankton surface push nets and oblique tows for comparing the catch of diadromous larval fish. Fisheries Research 86:99-104.

Paragamian, V. L., G. Kruse, and V. Wakkinen. 2001. Spawning habitat of Kootenai River white sturgeon postLibby Dam. North American Journal of Fisheries Management 21:22-33.

Perrin, C. J., L. L. Rempel, and M. L. Rosenau. 2003. White sturgeon spawning habitat in an unregulated river: Fraser River, Canada. Transactions of the American Fisheries Society 122:154-165.

Ross, R. M., R. M. Bennet, and T. W. H. Backman. 1993. Habitat use by spawning adult, egg, and larval American shad in the Delaware River. Rivers 4:227-238.

Rulifson, R. A. 1994. Status of anadromous Alosa along the East Coast of North America. Pages 134-158 in J. E.
Cooper, R. T. Eades, R. J. Klauda, and J. G. Loesch, editors. Anadromous Alosa Symposium. American Fisheries Society, Tidewater Chapter, Bethesda, Maryland.

Schmidt, R. E., B. M. Jessop, and J. E. Hightower. 2003. Status of river herring stocks in large rivers. Pages 171182 in K. E. Limburg and J. R. Waldman, editors. Biodiversity, status, and conservation of the world's shads. American Fisheries Society, Symposium 35, Bethesda, Maryland.

Smith, H. M. 1894. Statistics of the fisheries of the United States. U.S. Fish Commission Bulletin 13:389-417.

Smith, M. C. 2006. Habitat use of early Alosa spp. and striped bass Morone saxatilis in the lower Tar River, North Carolina. Master's thesis. East Carolina University, Greenville, North Carolina

Sparks, K. L. 1998. Identification of major spawning habitats used by American shad (Alosa sapidissima) in the Roanoke River, North Carolina. Master's thesis. North Carolina State University, Raleigh.

Sulak, K. J., and J. P. Clugston. 1998. Early life history stages of Gulf sturgeon in the Suwannee River, Florida. Transactions of the American Fisheries Society 127:758-771.

Tiffan, K. F., D. W. Rondorf, and J. J. Skalicky. 2005. Diel spawning behavior of chum salmon in the Columbia River. Transactions of the American Fisheries Society 134:892-900

Walburg, C. H., and R. P. Nichols. 1967. Biology and management of the American shad and status of the fisheries, Atlantic coast of the United States, 1960. U.S. Fish and Wildlife Service Fishery Bulletin, Special Scientific Report-Fisheries 550.

Walsh, H. J., L. R. Settle, and D. S. Peters. 2005. Early life history of blueback herring and alewife in the lower Roanoke River, North Carolina. Transactions of the American Fisheries Society 134:910-926.

Weisberg, S. B., and W. H. Burton. 1993. Spring distribution and abundance of ichthyoplankton in the tidal Delaware River. U.S. National Marine Fisheries Service Fishery Bulletin 91:788-797.

Williams, R. O., W. F. Grey, and J. A. Huff. 1975. Anadromous fish studies in the St. Johns River. National Marine Fisheries Service, Completion Report for the Study of Anadromous Fishes of Florida, Project AFCS-5, St. Petersburg, Florida.

Zar, J. H. 1999. Biostatistical analysis, 4th edition. PrenticeHall, Upper Saddle River, New Jersey. 